\title{
TINJAUAN PSIKOLOGI KESEHATAN \\ PADA PENDERITA PENYAKIT KAKI GAJAH KRONIS DI KABUPATEN BANDUNG
}

\author{
Ambar Sulianti \\ UIN Sunan Gunung Djati Bandung, Jl. A.H. Nasution 105 \\ e-mail: ambarleeanty@gmail.com
}

\begin{abstract}
Elephantiasis or Filariasis has been reported endemic in Kabupaten Bandung with potentially result in defects. This research aimed to explore health psychology of chronic Elephantiasis patients in Kabupaten Bandung. Qualitative-descriptive method has been used to explore the respondent's psychodynamics, health behavior, and treatment seeking behavior, while quantitative-descriptive method has been used to determine the percentage distribution. The result showed that there were three kind of respondent's psychodynamic namely denial (7.7\%), anxiety (85\%), and depression (7.7\%). Due to the lack of knowledge about the disease, the majority of respondents (77\%) were hiding their disease.Type of treatment seeking behaviors has been chosen by respondent namely relying to the paranormal $(92 \%)$, doctors (23\%), traditional physician (54\%), and acupuncturist (15\%).
\end{abstract}

Keywords: Elephantiasis, health psychology, psychodynamic, Kabupaten Bandung

\begin{abstract}
Abstrak
Penyakit kaki gajah dilaporkan endemis di Kabupaten Bandung dan berpotensi menimbulkan kecacatan. Penelitian ini bertujuan mengeksplorasi psikologi kesehatan pada penderita penyakit kaki gajah kronis di Kabupaten Bandung. Penelitian ini menggunakan deskriptifkualitatif untuk mengeksplorasi dinamika psikologis, perilaku kesehatan responden, dan perilaku pencarian pengobatan. Adapun metode deskriptif-kuantitatif digunakan untuk mengetahui sebaran presentasenya. Hasil penelitian ini menunjukkan bahwa terdapat tiga dinamika psikologis yaitu: penolakan $(7,7 \%)$, cemas $(85 \%)$, dan depresi $(7,7 \%)$. Perilaku penderita sebagian besar $(77 \%)$ menutupi penyakitnya karena minimnya pengetahuan. Pola perilaku pencarian pengobatan terdiri atas: mempercayakan pemeliharaan kesehatannya kepada paranormal $(92 \%)$, dokter $(23 \%)$, jamu-jamu dan refleksi tradisional (54\%), serta ahli akupunktur (15\%).
\end{abstract}

Kata kunci: penyakit kaki gajah, psikologi kesehatan, psikodinamika, Kabupaten Bandung.

\section{PENDAHULUAN}

Semua orang tentu berharap selalu berada dalam kondisi sehat. Namun kenyataannya setiap manusia pernah mengalami sakit. Sehat (Arab "Al-shihah"), dalam Islam bukan hanya merupakan sesuatu yang berhubungan dengan masalah fisik (jasmani), melainkan juga secara psikis (jiwa). Karena itulah Islam memperkenalkan konseps al-Shihhah wa alafiyat (lazim diucapkan sehat wal'afiat). Maksud dari konsep itu yakni suatu kondisi sehat di mana seseorang mengalami kesehatan yang paripurna, jasmani, dan rohani atau fisik dan psikis.
Psikologi kesehatan mencoba memahami keterkaitan antara kondisi sehat dan sakit, tidak hanya secara fisik tapi juga secara psikis. Psikologi kesehatan bertujuan untuk memahami dinamika psikologis individu yang tetap menjaga kesehatannya, dinamika psikologis individu yang sehat namun kemudian mendapat diagnosa penyakit kronis serta dinamika psikologis individu saat merespon keadaan sakit kronis yang sedang dialami. Salah satu penyakit kronis yang menjadi masalah kesehatan di Indonesia dan di dunia ialah penyakit kaki gajah.

Penyakit kaki gajah disebabkan oleh parasit cacing filaria yang menyerang 
kelenjar dan pembuluh limfe. Penyakit ini ditularkan melalui cucukan nyamuk vektor. Hingga saat ini telah diketahui ada 23 spesies nyamuk dari genus Anopheles, Culex, Mansonia, Aedes dan Armigeres yang tersebar luas dapat berperan sebagai vektor penular penyakit. Faktor demografi berpengaruh terhadap tingkat kejadian penyakit kaki gajah. Kantong-kantong daerah endemis biasanya merupakan daerah dataran rendah yang berawa dikelilingi oleh daerah bersemak belukar meskipun penyakit kaki gajah juga ditemukan di daerah perkotaan dan yang berbukit. (Cohen dan Small,1998; Ilyas, 1990; Oemijati, 1990). Mengacu pada data tentang tingginya kasus penyakit kaki gajah di dunia, daerah endemis penyakit kaki gajah tersebar luas di daerah tropis dan subtropis di seluruh dunia termasuk didalamnya Asia, Afrika, Cina, Pasifik Barat dan sebagian Amerika. Lebih dari 1 milyar manusia di dunia dilaporkan memiliki risiko menderita penyakit ini dan lebih dari 120 juta orang di 81 negara telah terinfeksi penyakit ini. (Bockarie, Taylor, dan Gyopong,2009).

Jenis cacing penyebab penyakit kaki gajah limfatik pada manusia adalah Wuchereria bancrofti, Brugia malayi dan Brugia timori. Ketiga cacing ini termasuk ke dalam Filum Nematoda, Superfamili Filaroidea, Famili Filariidae. Penyakit kaki gajah di Indonesia pertama kali dilaporkan oleh Haga dan van Eecke pada tahun 1889 di Jakarta yaitu dengan ditemukannya penderita penyakit kaki gajah dengan pembengkakan buah zakar. Pada saat itu pula Jakarta diketahui endemik penyakit kaki gajah limfatik yang disebabkan oleh cacing jenis $W$. bancrofti. Cacing $B$. malayi ditemukan pertama kali di dunia di Bireun, Sumatra Utara oleh Lichtenstein dan Brug (1927) berdasarkan morfologi mikrofilaria dari darah tepi pada penderita penyakit kaki gajah. Peneliti Pinhao (1961) dan David dan Edeson (1964,1965) telah menemukan jenis cacing yang baru dengan struktur stadium mikrofilaria yang mirip dengan mikrofilaria B.malayi, yang kemudian dikenal dengan B. timori, pada manusia di Timor Portugis. Jenis cacing yang sama juga ditemukan di Timor Barat, Flores dan Alor. (Soedomo, 1990; Helen F, McGarry, Leigh D, Plant and Taylor,MJ, 2005; Agoes, 1982; Sasa dan Manabu, 1979).

Program pemberantasan penyakit kaki gajah di Indonesia secara intensif dilakukan sejak tahun 1975 meliputi 21 dari 27 propinsi. Hasil yang dicapai cukup memuaskan, prevalensi penyakit secara nyata turun dari $13,3 \%$ menjadi 3,29\% pada tahun 1987. Penyakit kaki gajah kembali menjadi masalah kesehatan sejak tahun 1990 sejak ditemukan kasus limfoedema di Indonesia. Kasus-kasus baru kembali dilaporkan di Indonesia dan di beberapa negara di dunia. Hasil survai laboratorium tahun 2002 berdasarkan survey darah jari, rata-rata Mikrofilaria rate (Mf rate) 3,1\%, berarti sekitar 6 juta orang sudah terinfeksi cacing filaria dan sekitar 100 juta orang mempunyai resiko tinggi untuk tertular karena nyamuk penularnya tersebar luas. Data pada tahun 2006 berdasarkan survey darah jari menunjukkan sebanyak 321 kabupaten atau kota tersebar di 26 propinsi termasuk Jawa Barat dinyatakan sebagai lokasi yang endemis. Hasil pemetaan nasional pada tahun 2009 menyebutkan bahwa prevalensi mikrofilaria sebesar $19 \%$, artinya sekira 40 juta orang di dalam tubuhnya mengandung mikrofilaria dan dapat menjadi sumber penularan melalui berbagai jenis nyamuk kepada 125 juta penduduk yang tinggal di daerah sekitarnya. (Ditjen PP dan PL Depkes RI,2010; Onggowaluyo, Ismid IS, Sungkar,S. 1999; Cohen dan Small,1998; Ilyas, 1990; Sudomo, 1990; Oemijati, 1990).

Penyakit kaki gajah menjadi perhatian WHO hingga ditetapkan Kesepakatan Global untuk memberantas penyakit kaki gajah pada tahun 2020 (The Global Goal of Elimination of Lymphatic Penyakit kaki gajah as a Public Health problem by The Year 2020). Program pemberantasan penyakit kaki gajah terutama ditujukan 
untuk memutuskan rantai penularan dengan tujuan mengurangi angka infeksi (infection rate) pada manusia (Bockarie, Taylor, dan Gyopong,2009; Ilyas, 1990). Obat pilihan (Drug of Choice) yang digunakan dalam program ialah Dietilkarbamazin sitrat (DEC) yang diberikan kepada individual yang pada pemeriksaan darah tepi mengandung cacing filaria stadium mikrofilaria dan diberikan secara masal pada daerah endemis dengan hasil Survey Darah Jari (SDJ) positif mikrofilaria $>1 \%$.

Walaupun pengobatan masal penyakit kaki gajah gencar dilakukan sebagai ujung tombak program pemberantasan penyakit kaki gajah di Indonesia, potensi untuk terjadi reemerging masih tetap ada karena cakupan pengobatan di daerah endemis belum bisa tercapai $100 \%$, selain dari itu terdapat hewan-hewan di sekitar manusia yang berpotensi untuk berperan sebagai hospes reservoar dalam transmisi penyakit kaki gajah. Cacing jenis B. malayi berdistribusi luas di Indonesia dan di negara-negara Asia, memiliki kemampuan menimbulkan penyakit kaki gajah tidak hanya pada manusia tetapi juga pada hewan. (Ilyas, 1990, Sandhosam, 1963; Palmieri, 1985; Oemijati, 1990) Terdapat beberapa jenis hewan yang dapat bertindak sebagai hospes reservoir (hewan perantara) untuk B.malayi diantaranya kera, anjing, tupai, dan kucing. (Pong dkk, 2008; Kanjopas dkk, 2001). Hingga kini belum ditemukan vaksin untuk mencegah penyakit kaki gajah baik untuk manusia maupun hewan reservoar.

Penderita penyakit kaki gajah yang mengandung cacing filaria hidup di dalam darahnya, belum mengalami masalah pembengkakan pada awal penyakit. Apabila tidak ditangani dengan baik, penderita penyakit kaki gajah dapat jatuh pada stadium kronis yang menyebabkan pembengkakan anggota tubuh. Stadium kronis yang berawal dari kematian cacing dewasa. (Bennuru dan Nutman, 2009). Pada penyakit kaki gajah, Pada saat cacing dewasa mati, cacing akan dibungkus oleh jaringan ikat sebagai reaksi dari tubuh penderita sehingga terjadi granulasi yang akan menyumbat saluran getah bening tersebut. Sumbatan menyebabkan cairan getah bening tidak dapat naik kembali dan menyebabkan pembengkakan pada distal sumbatan. Dinding saluran limfe yang berada pada distal sumbatan lama kelamaan akan mengalami hiperselular dan membentuk skar atau pengerasan. Pengerasan pada dinding pembuluh limfe dan jaringan sekitarnya menyebabkan rusaknya katup pada pembuluh limfe dan kontraksi otot sekitar menjadi kurang efektif dalam melancarkan aliran limfe. Cairan limfe yang berkumpul pada area pembengkakan merupakan tempat yang subur untuk berkembang biak bakteri yang akan memperberat penyakit. Pada kulit timbul kelainan berupa penebalan akibat peningkatan keratinosit, fibroblast, dan adiposit. Dalam kondisi sudah terbentuk pengerasan, pembengkakan bersifat non pitting dan menetap. Pada kondisi ini bentuk kaki penderita penyakit kaki gajah kronis menyerupai kaki gajah sehingga disebut elefantiasis. Pembengkakan yang disebabkan oleh W.bancrofti dapat berukuran hingga $3 \mathrm{x}$ ukuran asalnya dan dapat terjadi pada buah zakar, vagina dan payudara. (Bennuru dan Nutman, 2009; Soedomo, 1990, Cook, 1996, Kurniawan, L 1994).

Penyakit ini dianggap menakutkan sebab pada fase kronis dapat menyebabkan cacat tubuh permanen karena jaringan pembuluh limfe dan pembuluh darah di sekitar organ tubuh itu mengalami pengerasan dan kerusakan. Bila sudah terjadi pembengkakan yang besar dan pengerasan, hingga kini belum ditemukan obatnya bahkan operasi pun kurang bermanfaat lagi sehingga menimbulkan kecacatan. Tercatat sebanyak 11.913 orang penderita penyakit kaki gajah di Indonesia tahun 2009 memasuki stadium kronis dan angka ini terus bertambah. Kondisi ini sungguh memprihatinkan karena masalah pembengkakan yang ditimbulkan oleh penyakit kaki gajah kronis tidak hanya 
merugikan secara estetika dan penurunan kemampuan mobilitas penderita, tetapi lebih jauh menyebabkan kecacatan yang menimbulkan permasalahan psikis dan sosial penderita. Kecacatan yang ditimbulkan oleh penyakit kaki gajah kronis mengakibatkan penderita mengalami penurunan rasa percaya diri. Selain itu, keterbatasan gerak akibat kaki yang besar menyebabkan penderita menarik diri dari interaksi sosial dan lambat laun menjadi pribadi yang tidak produktif dan tidak mandiri sehingga menjadi beban bagi keluarga, masyarakat, bangsa, dan negara. Kondisi ini diperparah dengan kurangnya rasa empati, pengetahuan, dan rasa persaudaraan dari masyarakat sekitar yang menjadikan penderita sebagai bahan pembicaraan bahkan malu bertetangga dengan penderita. Pada beberapa kasus dilaporkan adanya warga yang tinggal di sekitar penderita, mengumpulkan uang guna diberikan kepada penderita untuk mengusir penderita dari tempat tersebut (Harian Pikiran Rakyat, 2011)

Penyakit menyebabkan kecacatan fisik, stigma sosial, serta penurunan kualitas hidup. Hingga kini belum ada pengobatan yang efektif dapat mengecilkan dan mengembalikan bentuk kaki penderita kembali seperti semula. Hal ini tentu berdampak kepada psikologi penderita. Data hasil riset di Kabupaten Bandung menunjukkan sampai Desember 2011 tercatat sebanyak 51 penderita penyakit kaki gajah kronis yang tersebar di 15 Kecamatan (Dinas Kesehatan Kabupaten Bandung, 2012). Dampak fisik dari penyakit ini adalah menurunnya produktifitas kerja individu, keluarga dan masyarakat sehingga menimbulkan kerugian ekonomi yang besar. Penderita yang sudah cacat biasanya akan merasa rendah diri dan mengasingkan diri dari masyarakat. Selain itu mereka tidak dapat bekerja dengan baik sehingga hidupnya sehari-hari tergantung kepada orang lain. Hal ini berakibat pada penderita yang tidak dapat bekerja optimal bahkan sebagian besar tidak mampu lagi untuk bekerja sehingga menjadi beban keluarga, masyarakat dan negara. Penelitian yang dilakukan oleh Suma dkk (2003) di India menyebutkan penyakit kaki gajah penurunkan produktifitas kerja. Di Indonesia telah dihitung oleh Gani dalam perhitungan berdasarkan jumlah penderita penyakit kaki gajah kronis tahun 2009 ditunjukkan bahwa kerugian yang ditimbulkan oleh penyakit kaki gajah kronis sebesar Rp. 10.399.266.093,00 per tahun. Kumari dkk dari hasil risetnya pada tahun 2005 melaporkan bahwa tingkat permasalahan psikososial akibat penyakit kaki gajah berhubungan dengan keparahan pembengkakan anggota gerak.

Untuk menangani penderita penyakit kaki gajah kronis yang sudah mengalami pembengkakan menetap, pemerintah melakukan program pelayanan konsultasi melalui puskesmas. Program penanganan filarias kronis yang ada tidak dapat mengecilkan atau mengembalikan kondisi anggota badan penderita kembali ke bentuk semula karena sampai saat ini belum ditemukan metode pengobatan untuk menyembuhkan penyakit kaki gajah yang sudah kronis. Program yang ada, bertujuan mencegah terjadinya infeksi sekunder yang nantinya dapat memperberat penyakit, membatasi kecacatan, dan mengurangi ketidakmampuan pada penderita. Program penatalaksanaan penderita penyakit kaki gajah kronis mengacu program dari WHO (World Health Organization) yang terdiri atas penjagaan kebersihan dan kesehatan kulit, olah gerak, kompresi, dan elevasi kaki. Hingga saat ini belum ada konsep pendekatan yang dilakukan untuk menangani permasalahan psikologis penderita penyakti kaki gajah. Kondisi ini menyebabkan kecacatan yang ditimbulkan oleh penyakit penyakit kaki gajah sangat berdampak pada psikologi penderita. Penderita menjadi malu dan meninggalkan pekerjaan yang biasa dilakukan sewaktu sehat. Kondisi ini diperparah dengan kurangnya dukungan psikis dari warga di sekitar penderita. Hingga kini belum ada penelitian yang bertujuan mengeksplorasi bagaimana kon- 
disi dan respon psikologi penderita penyakit kaki gajah di Kabupaten Bandung terhadap penyakit yang dideritanya. Mempertimbangkan kondisi ini, perlu diteliti bagaimana tinjauan psikologi kesehatan terhadap penderita penyakit kaki gajah kronis di Kabupaten Bandung.

Berdasarkan latar belakang di atas, penulis merumuskan masalah sebagai berikut:

1. Dinamika psikologis apa saja dialami oleh penderita penyakit kaki gajah kronis di Kabupaten Bandung setelah mengetahui penyakitnya?

2. Bagaimana perilaku penderita penyakit kaki gajah di Kabupaten Bandung terhadap penyakit yang dideritanya?

3. Bagaimana perilaku penderita penyakit kaki gajah di Kabupaten Bandung terhadap pencarian pengobatan penyakit yang dideritanya (health seeking behaviour)?

Secara umum tujuan penelitian ini ialah mengeksplorasi lebih dalam bagaimana penderita penyakit kaki gajah kronis di Kabupaten Bandung ditinjau dari psikologi kesehatan dengan penjabaran sebagai berikut.

1. Mengeksplorasi dinamika psikologis apa saja dialami oleh penderita penyakit kaki gajah kronis di Kabupaten Bandung setelah mengetahui penyakitnya.

2. Menganalisis perilaku penderita penyakit kaki gajah di Kabupaten Bandung terhadap penyakit yang dideritanya.

3. Menganalisis perilaku penderita penyakit kaki gajah di Kabupaten Bandung terhadap pencarian pengobatan penyakit yang dideritanya (health seeking behaviour).

\section{METODE PENELITIAN}

Penelitian ini merupakan penelitian deskriptif-kualitatif. Fokusnya adalah penggambaran secara menyeluruh tentang permasalahan psikososial akibat penyakit kaki gajah yang dialami penduduk di Kabupaten Bandung. Daya yang dihasilkan berupa kata-kata tertulis atau lisan dari penderita dan keluarga penderita penyakit kaki gajah serta perilaku yang dapat diamati. Metode penelitian ini menggunakan metode survey deskriptif untuk menggambarkan karakteristik psikologi kesehatan penderita penyakit kaki gajah kronis di Kabupaten Bandung.

Subjek penelitian atau responden ini adalah 13 penderita penyakit kaki gajah kronis di Kota Bandung yang diambil secara acak sederhana. Pengumpulan data dilakukan melalui observasi dengan cara peneliti melibatkan diri untuk mewawancara responden atau informan. Alat pengumpul data, dengan demikian digunakan pedoman observasi dari wawancara dan quisionere. Selanjutnya dilakukan pengabsahan data sebagai hal yang mutlak dalam proses penelitian, dengan cara triangulasi, yaitu mencari dari berbagai sumber data, peneliti, teori, dan metode, yaitu observasi langsung sebagai metode utama, dan wawancara untuk konfirmasi hasil observasi. Disamping itu, hasil observasi juga dikonfirmasikan kepada teori-teori yang relevan.

\section{Subjek Penelitian atau Responden}

Subjek penelitian/reponden pada

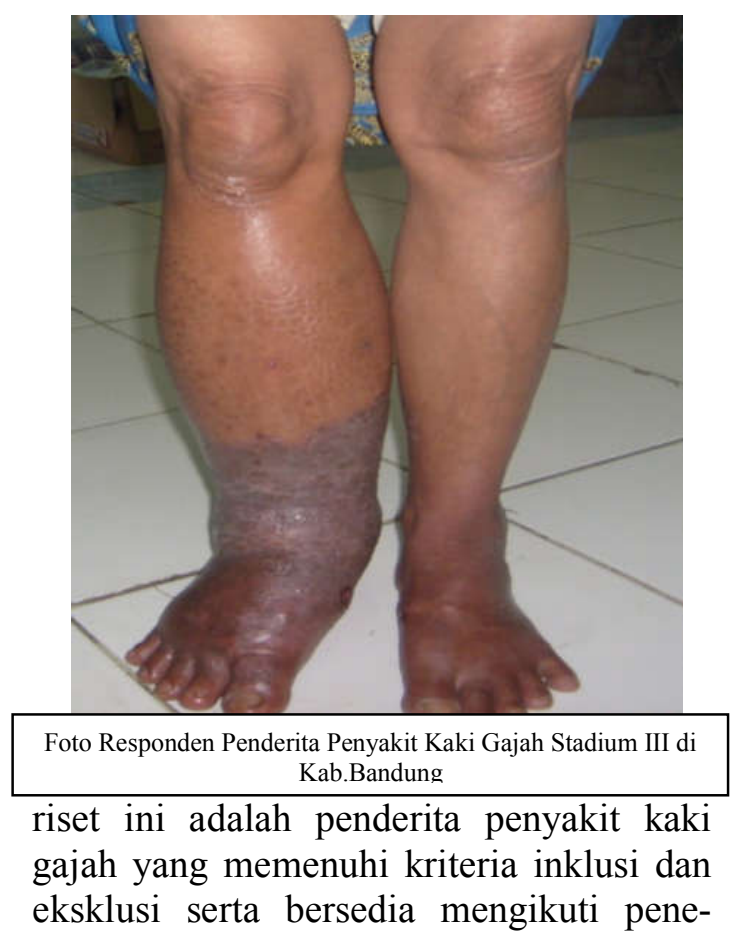


litian dengan menandatangani lembar persetujuan (informed concent). Populasi target penelitian ini ialah seluruh penderita penyakit kaki gajah kronis stadium III. Populasi terjangkau penelitian ini ialah seluruh penderita penyakit kaki gajah kronis stadium III yang tercatat pada Dinas Kesehatan Kabupaten Bandung. Jumlah sampel yang diambil pada penelitian ini ialah 13 orang.

Kriteria inklusi untuk penderita penyakit kaki gajah kronis pada penelitian ini ialah sebagai berikut.

- Berdasarkan anamnesis, pemeriksaan klinis, dan data dari puskesmas didiagnosis sebagai penyakit kaki gajah kronis.

- Mengalami pembengkakan stadium III menurut kriteria WHO (terjadi peningkatan volume dalam jumlah besar pada anggota gerak diikuti perubahan pada kulit dan jaringan subkutan)

- Penderita penyakit kaki gajah berusia $30-65$ tahun.

Dasar pemilihan stadium pembengkakan pada penderita penyakit kaki gajah pada penelitian ini ialah klasifikasi WHO menurut histopatologis yaitu sebagai berikut.

- Stadium I, merupakan stadium pembengkakan awal yang dapat diatasi dengan meninggikan (elevasi) anggota badan. Pembengkakan ini lebih disebabkan karena akumlasi dairan matriks ekstraselur lar yang berbentuk gelatin.

- Stadium II, di mana pada stadium ini pembengkakan tidak berkurang spontan dengan elevasi. Pada fase ini limfe tersumbat oleh pengerasan (fibrosis) dan cairan berubah menjadi bentuk gelatinhidratid, matriks ekstraselular merupakan glikosaminoglikan.

- Stadium III, yang merupakan stadium pembengkakan menetap. Pada stadium ini terjadi peningkatan volume dalam jumlah besar pada anggota gerak diikuti perubahan pada kulit (dermatosklerosis) dan jaringan di bawah kulit (subkutis).

Adapun kriteria eksklusinya mengalami gangguan jiwa.

\section{Lokasi Penelitian}

Penelitian ini dilakukan di Kabupaten Bandung, propinsi Jawa Barat. Berdasarkan pengumpulan data dari penelitian pendahuluan di Kabupaten Bandung hingga tahun 2011 terdapat 51 penderita penyakit kaki gajah kronis yang telah mengalami pembengkakan pada anggota tubuhnya. Penderita tersebar di beberapa Desa yaitu Desa Nanjung, Karang Tinggal, Cipedes, Neglasari, Cikalong, Cimaung, Langonsari, Margahurip, Margahayu Tengah, Manggahang, Padamulya, Pangguh, Solokan Jeruk, Rancakole, Campaka mulya, Wangisagara, Majakarta, Padasuka, Jatisari, Cingcin, Parungserab, Mekar Rahayu, Ciluncat, Cangkuang, Jelekong, Rancamanyar, Ciluncat, Sangkan-hurip, Bojong Malaka, Sukamaju, dan Manggung Harja. Dari 51 penderita kaki gajah tersebut, yang bertindak sebagai subjek penelitian ialah 13 penderita penyakit kaki gajah di kabupaten Bandung yang sudah mengalamai pembengkakan stadium III serta memenuhi kriteria inklusi dan eksklusi.

\section{Jenis dan Sumber Data}

Penelitian ini menggunakan jenis data kualitatif dan data kuantitatif. Data kualitatif adalah data yang berupa keterangan atau kata-kata yang diperoleh dari sumber data, sedangkan data kuantitatif adalah data yang berupa angka. Data kualitatif digunakan sebagai dasar untuk mengetahui permasalahan psikologi kesehatan akibat penyakit kaki gajah yang dialami penduduk di Kabupaten Bandung. Data kuantitatif digunakan untuk mengetahui sebaran presentase dinamika psikologis yang dialami oleh penderita penyakit kaki gajah kronis di Kabupaten Bandung setelah mengetahui penyakitnya, perilaku penderita penyakit kaki gajah di Kabupaten Bandung terhadap penyakit yang dideritanya, serta perilaku penderita penyakit kaki gajah di Kabupaten Bandung terhadap pencarian pengobatan penyakit yang dideritanya (health seeking behavior). 
Berdasarkan cara memperolehnya, penelitian ini menggunakan data primer dan sekunder. Data primer yaitu data yang dikumpulkan dan diolah sendiri oleh peneliti secara langsung dari objeknya. Data primer penelitian ini adalah jawaban yang diberikan penderita secara lisan yang disadur menjadi bentuk tulisan oleh peneliti.

Untuk mendapatkan data/informasi yang lebih lengkap, dibutuhkan data sekunder dari informan yaitu keluarga penderita. Informan yang baik, harus memenuhi beberapa kriteria informan, yaitu:

(1) Keluarga penderita yang berdomisili di rumah penderita atau satu rukun tetangga dengan penderita;

(2) Berusia antara 30 - 65 tahun dan tidak pikun sehingga mampu memberikan informasi berupa data yang representatif;

(3) Tidak cacat wicara;

(4) Sehat rohani;

(5) Berpendidikan serendah-rendahnya setingkat SD;

(6) Mampu diajak berkomunikasi;

(7) Bersedia menjadi informan;

(8) Dikenal sebagai warga yang baik oleh masyarakat di sekitarnya.

\section{Instrumen Penelitian}

Dalam penelitian ini data yang diteliti adalah data lisan dan tulisan. Untuk mendapatkan data dibutuhkan alat bantu berupa daftar pertanyaan, sound recorder pada handfon (HP), buku catatan, dan alat tulis. Daftar pertanyaan berisi pertanyaanpertanyaan yang ditanyakan secara lisan. Sound recorder HP digunakan untuk merekam jawaban yang dikemukakan oleh penderita dan informan. Hasil rekaman kemudian ditranskripsikan melalui pencatatan sehingga memudahkan untuk mengelompokkan data. Buku catatan dan alat tulis digunakan untuk membuat catatan hasil wawancara.

\section{Metode dan Teknik Penyediaan Data}

Data dikumpulkan dengan metode simak atau penyimakan, yaitu menyimak bermacam-macam dinamika psikologis yang dialami oleh penderita penyakit kaki gajah kronis di Kabupaten Bandung setelah mengetahui penyakitnya, perilaku penderita penyakit kaki gajah di Kabu-paten Bandung terhadap penyakit yang dideritanya, serta perilaku penderita penyakit kaki gajah di Kabupaten Bandung terhadap pencarian pengobatan penyakit yang dideritanya (health seeking behavior). Teknik simak libat cakap dilakukan dengan menyimak sekaligus berpartisipasi dalam pembicaraan. Peneliti terlibat langsung dalam dialog baik secara aktif maupun reseptif. Aktif, artinya peneliti ikut berbicara dalam dialog sedangkan reseptif artinya hanya mendengarkan pembicaraan subjek penelitian dan informan.

Data tulis dikumpulkan dengan metode simak yang dibantu dengan teknik lanjutan berupa teknik catat. Di samping dengan metode simak, data dalam penelitian ini juga dikumpulkan dengan metode cakap. Metode cakap dibantu dengan teknik dasar teknik pancing, sedangkan teknik lanjutannya adalah teknik cakap semuka, teknik rekam, dan teknik catat. Teknik pancing dilakukan dengan pemancingan. Artinya, peneliti mengajukan berbagai macam pertanyaan agar subjek penelitiandan informan mau mengeluarkan berbagai macam dinamika psikologis yang dialami oleh setelah mengetahui penyakitnya, perilaku apa saja yang dilakukan, serta perilaku pencarian pengobatan yang telah dilakukan.

Teknik pancing dilakukan dengan langsung, tatap muka atau bersemuka. Pada saat teknik pancing dan teknik cakap semuka diterapkan, sekaligus dioperasikan teknik rekam. Artinya, peneliti merekam pembicaraan dalam teknik pancing dan teknik cakap semuka. Hasil rekaman itu kemudian ditindaklanjuti dengan teknik catat.

\section{Metode dan Teknik Analisis Data}

Untuk mendapatkan hasil analisis data yang baik dilakukan sejumlah tahapan. Tahapan-tahapan yang dimaksud adalah (1) transkripsi data dari bahasa lisan ke dalam bahasa tulis dan mencatat data 
tertulis, (2) mengelompokkan jawaban (3) sebaran presentasi dinamika berdasarkan kelompok.

Dalam deskriptif eksploratif ini, analisis data dilakukan bersamaan dengan pengumpulan data. Pertama, melakukan analisis domain, dengan cara mereduksi data yang diperoleh, diklasifikasikan dalam domain untuk memperoleh gambaran yang bersifat umum dan relatif menyeluruh dari suatu fokus permasalahan. Kegiatan ini dilakukan bersama observasi deskriptif.

Kedua, analisis taksonomik, yang berusaha merinci lebih lanjut, mengorganisasikan dan menghimpun elemenelemen yang sama dalam suatu domain yang dianggap penting dan relevan dalam fokus permasalahan penelitian. Tahap ini dilakukan bersama dengan observasi terfokus.

Ketiga, analisis komponensial, dengan cara mengorganisasikan kontras antar elemen dalam domain yang diperoleh dari hasil observasi selektif.

Keempat, hasil dari ketiga analisis dilanjutkan dengan analisis tema sebagai suatu proses interpretasi, dengan cara mendeskripsikan secara menyeluruh dan menampilkan makna dari objek yang menjadi fokus penelitian untuk menjaga objektivitas penafsiran data ini, kembali digunakan referensi teoritik untuk memberikan penjelasan dan wawasan yang luas terhadap domain, taksonomik, dan komponen yang ditemukan dalam penelitian.

\section{HASIL PENELITIAN DAN PEMBA- HASAN}

Menurut Skinner dalam Notoatmodjo (2007) merumuskan bahwa perilaku merupakan respons atau reaksi seseorang terhadap stimulus (rangsangan dari luar). Oleh karena perilaku ini terjadi melalui proses adanya stimulus terhadap organisme, dan kemudian organisme tersebut merespons, maka teori Skinner ini disebut
"S-O-R" atau Stimulus Organisme Respons.

Pada penelitian ini yang bertindak sebagai stimulus ialah penyakit kaki gajah kronis. Perilaku kesehatan yang diamati adalah dinamika psikologis penderita terhadap keadaan sakitnya, respons penderita terhadap penyakitnya yang memiliki unsur-unsur perilaku dengan sakit dan penyakit, dan perilaku pencarian pengobatan (health seeking behaviour).

\section{Dinamika Psikologis Dialami Oleh Penderita Penyakit Kaki Gajah Kronis Di Kabupaten Bandung}

Terdapat beberapa respon emosional yang muncul pada penderita penyakit kaki gajah kronis setelah mengetahui penyakit yang dideritanya.

1) Penolakan (Denial)

Reaksi ini terjadi pada 7,7\% penderita penyakit kaki gajah kronis di Kabupaten Bandung. Atas penyakit yang dideritanya ini, penderita menolak untuk mengakui bahwa penyakit yang diderita sebenarnya berat dan meyakini bahwa penyakit kronis ini akan segera sembuh dan hanya akan memberi efek jangka pendek (menolak untuk mengakui bahwa penyakit kronis ini belum tentu dapat disembuhkan secara total dan menolak untuk mengakui bahwa terdapat risiko kecacatan akibat penyakit ini).

2) Cemas

Reaksi kecemasan merupakan reaksi yang paling umum terjadi pada penderita penyakit kaki gajah kronis (85\%). Responden merasa terkejut atas reaksi dan perubahan yang terjadi pada dirinya. Kecemasan yang dialami pada penderita penyakit kaki gajah kronis di Kabupaten Bandung berupa: cemas panyakitnya tidak bisa disembuhkan, cemas karena penyakitnya mengganggu kemampuan mobilitas penderita, cemas akan menjadi cacat dan menjadi beban bagi keluarganya, cemas tidak bisa menghidupi keluarganya karena penyakitnya, cemas karena khawatir penyakitnya membutuhkan 
dana yang besar untuk pengobatan. Rasa nyeri disertai panas membakar yang diderita sewaktu terjadi peradangan pada kelenjar dan saluran limfe bahkan menyebabkan beberapa penderita membayangkan kematian yang akan terjadi padanya. Reaksi tersebut memberikan efek emosional tersendiri.

3) Depresi

Depresi terjadi pada $7,7 \%$ penderita penyakit kaki gajah kronis. Depresi dialami oleh penderita wanita yang didiagnosis sakit kaki gajah di usianya yang ke 36 tahun. Penderita tersebut menutup diri hingga tidak mau menikah karena malu.

Untuk dapat memahami respon yang terjadi atas perubahan yang ada pada penderita penyakit kronis, perlu pemahaman yang mendalam tentang diri individu (self) itu sendiri. Self merupakan salah satu konsep utama dalam ilmu psikologi. Para psikolog mengacu pada self concept sebagai keyakinan atas kualitas dan penilaian yang dimiliki seseorang. Penyakit kronis dapat menghasilkan perubahan yang drastis pada self concept dan self esteem. Beberapa perubahan yang ada bisa bersifat sementara, walaupun ada juga yang bersifat permanen. Self concept itu sendiri merupakan bagian dari self evaluation termasuk didalamnya beberapa aspek di antaranya body image. Body image merupakan penilaian dan evaluasi atas fungsi dan penampilan fisik seseorang. Body image yang rendah berhubungan dengan harga diri yang rendah diikuti dengan terjadinya peningkatan depresi serta kecemasan. Keadaan penyakit kaki gajah kronis menyebabkan kecacatan dan merusak estetika dari anggota badan penderita konsep diri individu yang bersangkutan menjadi terkoyak dan rusak.

Perilaku Penderita Terhadap Penyakit Kaki Gajah di Kabupaten Bandung Terhadap Penyakit yang Dideritanya

Psikologi Kesehatan berkembang untuk memahami pengaruh psikologis terhadap kesehatan termasuk diantaranya untuk menjelaskan apa yang mereka lakukan saat mereka jatuh sakit. Selain itu, psikologi kesehatan mempromosikan intervensi untuk membantu orang agar tetap sehat dan juga mengatasi kesakitan yang dideritanya.

Sebagaimana kita ketahui bahwa masyarakat Indonesia terdiri dari banyak suku bangsa yang mempunyai latar budaya yang beraneka ragam yang berpengaruh terhadap tingkah laku manusia, termasuk perilaku kesehatan. Dengan demikian petugas kesehatan dalam memberikan pelayanan kesehatan kepada masyarakat dangan latar budaya yang beraneka ragam perlu mengetahui budaya dan masyarakat yang dilayaninya, agar pelayanan kesehatan yang diberikan kepada masyarakat akan memberikan hasil yang optimal yaitu meningkatkan kesehatan masyarakat.

Taylor memberikan definisi kebudayaan sebagai keseluruhan yang kompleks yang didalamnya terkandung ilmu pengetahuan, kepercayaan, kesenian, moral, hukam, adat istiadat dan kemampuan lain serta kebiasaan-kebiasaan yang didapat manusia sebagai anggota masyarakat (Taylor, 2008). Koentjaraningrat mendefinisikan bahwa kebudayaan adalah seluruh kelakuan dan hasil kelakuan manusia yang teratur oleh tata kelakuan yang haus didapatkannya dengan belajar dan yang semuanya tersusun dalam kehidupan masyarakat

Beberapa aspek sosial budaya yang mempengaruhi perilaku kesehatan dan status kesehatan.yang pertama yaitu:

1) umur;

2) jenis kelamin;

3) pekerjaan;

4) sosial ekonomi.

Tiga belas penderita penyakit kaki gajah yang menjadi subjek penelitian kualitatif ini $61,3 \%$ berada pada usia produktif, $54 \%$ berjenis kelamin perempuan, 1 orang bekerja sebagai petani, 2 orang berwira usaha dibantu keluarganya, sisanya kini menganggur karena kondisi kesehatannya terganggu.

Berdasarkan hasil wawancara mendalam kepada para responden diperoleh 
data bahwa sebagian besar yaitu 10 dari 13 orang responden menutupi penyakitnya. Mereka malu menderita penyakit yang menyebabkan pembengkakan anggota tubuhnya sehingga menyembunyikan diri di dalam rumah dan tidak memberi tahu tetangga atau bahkan kerabatnya kecuali kerabat yang tinggal serumah. Jika terpaksa harus ke luar rumah, mereka menyembunyikan pembengkakan anggota tubuhnya dengan cara menggunakan jaket atau baju dan celana yang longgar dan panjang. Mereka berobat secara diam-diam dan tidak melaporkan kepada puskesmas tempat wilayah kerja mereka. Delapan dari 10 penderita yang menutup diri baru mengetahui penyakit yang dideritanya dari berita di televisi. Sikap tertutup ini didasari oleh rasa malu dan kekhawatiran akan dijauhi oleh orang lain karena takut tertular oleh mereka. Hal ini disebabkan karena minimnya pengetahuan penderita penyakit kaki gajah dan penduduk Kabupaten Bandung tentang cara penularan penyakit ini. Penyakit kaki gajah tidak akan menular melalui sentuhan atau pun kontak langsung dengan penderita. Penyakit kaki gajah menular dari satu penderita ke penderita lain melalui cucukan nyamuk vektor. Hampir semua jenis nyamuk berpotensi menyebarkan penyakit ini.

Faktor-faktor yang membedakan respons penderita terhadap penyakit kaki gajah ini merupakan disebut determinan perilaku. Determinan perilaku ini dapat dibedakan menjadi dua, yaitu: determinan internal dan eksternal. Dengan demikian perilaku adalah merupakan totalitas penghayatan dan aktivitas seseorang yang merupakan hasil bersama atau resultant antara berbagai faktor, baik faktor internal maupun eksternal. Dengan perkataan lain perilaku manusia sangatlah kompleks, dan mempunyai bentangan yang sangat luas. Sehingga membagi perilaku manusia menjadi 3 domain, ranah atau kawasan yakni: kognitif, afektif, psikomotor.

Determinan internal, yakni karakteristik orang yang bersangkutan, yang bersifat given atau bawaan, misalnya: tingkat kecerdasan, tingkat emosional, jenis kelamin, dan sebagainya. Dalam hal ini $77 \%$ penderita berpendidikan SD atau lulus SD. Tingkat pendidikan ini dapat berpengaruh terhadap tingkat kecerdasan dan daya tangkap terhadap penjelasan penyakit yang diberikan oleh tenaga kesehatan. Sosialisasi penyakit kaki gajah telah dilakukan di Kabupaten Bandung sejak 2009, namun berdasarkan hasil wawancara terhadap responden, hanya $23 \%$ responden yang memiliki pengetahu-an kesehatan tentang penyakit kaki gajah pada tahap "memahami (comprehension). Sisa-nya yaitu $77 \%$ responden berada pada level tahu (know). Sebagian besar hanya tahu bahwa mereka menderita penyakit kaki gajah tetapi dapat menjelaskan secara benar tentang objek yang diketahui dan dapat menginterpretasikan materi tersebut secara benar. Tahu merupakan tingkat yang paling rendah.

Dalam domain kognitif, pengetahuan dibagi dalam 6 tingkatan yaitu:

1) Tahu (know)

Tahu diartikan sebagai mengingat suatu materi yang telah dipelajari sebelumnya, termasuk mengingat kembali (recall). Tahu merupakan tingkat yang paling rendah dan untuk mengukur bahwa orang tahu tentang apa yang dipelajari antara lain menyebutkan, meguraikan, mendefinisikan, menyatakan dan sebagainya.

2) Memahami (comprehension)

Memahami diartikan sebagai suatu kemampuan untuk

3) Aplikasi (Aplication)

Aplikasi ialah kemampuan untuk menggunakan materi yang telah dipelajari pada situasi yang real atau penggunaan hukum-hukum, rumus, metode, perinsip dan sebagainya dalam konteks atau situasi yang lain.

4) Analisis (analysis)

Analisis ialah kemampuan untuk menjabarkan materi atau suatu objek ke dalam komponen-komponen, tetapi masih di dalam satu struktur 
organisasi, dan masih ada kaitannya satu sama lain.

5) Sintesis (Synthesis)

Sintesis adalah suatu kemampuan untuk menyusun formulasi baru dari formulasi-formulasi yang ada misalnya menyusun, merencanakan, meringkas, menyesuaikan dan sebagainya terhadap suatu teori.

6) Evaluasi (Evaluation)

Evaluasi berkaitan dengan kemampuan untuk melakukan justifikasi atau penilaian terhadap suatu materi. Evaluasi ini didasarkan pada suatu kriteria yang ditentukan sendiri atau menggunakan kriteria-kriteria yang telah ada.

Tingkat pengetahuan yang rendah pada sebagian besar penderita penyakit kaki gajah kronis di Kabupaten Bandung juga mempengaruhi sikap penderita. Sikap merupakan reaksi atau respon yang masih tertutup dari seseorang terhadap suatu stimulus atau objek. Sikap mempunyai 3 komponen pokok (Alport dalam Notoatmodjo, 2007) yaitu:

1) Kepercayaan (keyakinan), ide dan konsep terhadap suatu objek.

Sebagian besar penderita penyakit kaki gajah kronis di Kabupaten Bandung (92\%) meyakini bahwa penyakit yang dideritanya merupakan takdir yang harus mereka terima dengan pasrah. Delapan dari 13 responden bahkan meyakini bahwa penyakitnya adalah akibat guna-guna dari pihak yang tidak menyukai mereka, dua dari 13 resopnden masih meragukan apakah ada faktor guna-guna atau murni penyakit.

2) Kehidupan emosional atau evaluasi terhadap suatu objek.

Akibat salahnya keyakinan yang mereka yakini benar, kehidupan emosional mereka menjadi kurang stabil. Mereka menjadi mudah curiga terhadap orang yang berkunjung ke rumah mereka dan menjadi mudah marah. Kehidupan bertetangga di mana satu keluarga berkunjung kepada keluarga lain yang berdekatan tidak lagi dipandang sebagai habluminanas tetapi dinilai sebagai keingintahuan lebih terhadap penyakit yang mereka sembunyikan.

3) Kecenderungan untuk bertindak (tend to behave).

Berawal dari kurangnya pengetahuan dan berdasar pada keyakinan yang salah menyebabkan penderita penyakit kaki gajah kronis di Kabupaten Bandung menutup diri dari sosialisasi hidup bermasyarakat. Sikap menutup diri ini justru menyebabkan lebih tertutupnya wawasan tentang penyakit yang dideritanya dan membuat keadaan penderita menjadi lebih parah dari waktu ke waktu karena kurangnya awareness sehingga penyakitnya tidak ditangani dengan benar.

Sikap yang keliru ini kemudian berdampak kepada praktek atau tindakan yang keliru pula. Tindakan ini terdiri atas : persepsi, respon terpimpin, mekanisme, dan adopsi. Akibat dari persepsi yang keliru ketika tetangga berkunjung, mereka curiga akan maksud kedatangannya dan bersembunyi di dalam rumah. Mereka tidak mau membukakan pintu pada tamu datang dan menolak menemui tamu yang berkunjung.

Determinan eksternal yang berpengaruh dalam membentuk perilaku penderita penyakit kaki gajah di Kabupaten Bandung yaitu diantaranya lingkungan dan budaya. Determinan eksternal ini sering merupakan faktor yang dominan yang mewarnai perilaku seseorang. Masya-rakat Kabupatan Bandung banyak mem-percayai tahayul berupa kutukan atau santet sehingga penderita penyakit kaki gajah mengalami kekhawatiran yang berlebihan digosipkan terkena kutukan dan santet. Kondisi tertutup ini memperparah keadaah sehingga penderita menjadi termaginalkan. 


\section{Perilaku Penderita Penyakit Kaki Gajah di Kabupaten Bandung Ter- hadap Pencarian Pengobatan Penyakit yang Dideritanya (Health Seeking Behaviour).}

Perilaku pencarian pengobatan menyangkut upaya atau tindakan seseorang pada saat menderita penyakit, mulai dari mengobati sendiri (self-treatment) sampai mencari bantuan ahli. Model perilaku kese-hatan yang dapat menggambarkan bagai-mana sebuah perilaku terbentuk dikenal dengan Health Belief Model (HBM). Ro-senstock (1988) mengemukakan bahwa HBM berdasarkan pada empat elemen persepsi seseorang, yaitu:

a. Perceived suscepilbility: penilalan indlvidu mengenai kerentanan mereka terhadap suatu penyakit

b. Perceived seriousness: penilaian individu mengenai seberapa serius kondisi dan konsekuensi yang ditimbulkan oleh penyakit tersebut

c. Perceived barriers: penilaian individu mengenai besar hambatan yang ditemui untuk mengadopsi perilaku kesehatan yang disarankan, seperti hambatan finansial, fisik, dan psikososial

d. Perceived benefits: penilaian individu mengenai keuntungan yang didapat dengan mengadopsi perilaku kesehatan yang disarankan.

Ketika seseorang didiagnosa sakit penyakit kaki gajah berstadium kronis, dimana pengobatan medis sudah tidak mungkin diterima oleh penderita, maka individu tersebut akan mengalami goncangan psikologis yang hebat. Kecacatan adalah salah satu kepastian bagi para penderita penyakit kaki gajah kronis. Berjalannya waktu baik itu pendek atau panjang, bagi para para penderita penyakit kaki gajah kronis adalah hari-hari yang menyiksa karena mereka menjadi beban bagi orang lain. Berbagai macam peran hidup yang dijalani selama ini pasti akan menghadapi kendala baik itu disebabkan karena kendala fisik, psikologis, sosial, budaya maupun spiritual. Demikian pula orang-orang di sekitar para penderita penyakit kaki gajah kronis, tentunya juga mengalami penderitaan yang hampir sama karena keluarga dan orang-orang yang dekat dengan pasien akan turut merasakan penderitaannya.

Manusia secara umum ketika menghadapi sakit pasti akan berusaha untuk mengobati sakit yang diderita dengan berbagai macam cara. Perilaku health seek-ing pasti akan dilakukan baik itu dengan tujuan untuk meredakan sakit maupun bertujuan untuk mengobati sakit. Perbedaan kondisi fisik, psikologis, sosial, kultural maupun spiritual para penderita penyakit kaki gajah kronis mempengaruhi perilaku pencarian pengobatan para penderita penyakit kaki gajah kronis. Oleh karena itu, perilaku pencarian pengobatan para penderita penyakit kaki gajah kronis berbeda antara satu dengan lainnya.

Pola perilaku pencarian pengobatan pada penderita penyakit kaki gajah kronis di Kabupaten Bandung dapat dibedakan menjadi

1) Tiga orang mempercayakan pemeliharaan kesehatannya kepada seorang ahli kesehatan profesional seperti dokter (23\%).

2) Dua orang pernah mempercayakan pengobatan sakitnya kepada ahli kesehatan non dokter seperti ahli akupunktur (15\%).

3) Dua belas orang pernah mempercayakan kesehatannya kepada pengobatan dengan pendekatan spiritual kepada paranormal $(92 \%)$.

4) Tujuh orang pernah mempercayakan penyembuhan sakitnya kepada pengobatan tradisional seperti jamujamu dan refleksi tradisional (54\%).

Faktor-faktor yang mempengaruhi perilaku pencarian pengobatan merupakan sebuah hasil interaksi yang kompleks dan holistik oleh individu dengan lingkungan yang mempengaruhinya beserta pelayanan kesehatan yang ada. Perubahan salah satu aspek mungkin dapat menyebabkan perubahan perilaku, akan tetapi kadangkala juga tidak menyebabkan perubahan 
apapun, tergantung pada individu yang berperilaku. Fenomena pengobatan pada penderita penyakit kaki gajah kronis di Kabupaten Bandung merupakan suatu respon rasional masyarakat yang sedang berperanan sakit dalam rangka mencari kesembuhan akan penyakitnya.

Perilaku secara umum adalah suatu fungsi dari individu dan lingkungannya. Perilaku individu tidak hanya ditentukan oleh faktor individu (segala sesuatu yang terkait langsung dengan diri individu seperti: pola kepribadian, sikap, perasaan, emosi, pengetahuan dan lain-lain), tetapi juga ditentukan oleh faktor lingkungan baik terkait dengan lingkungan fisik maupun lingkungan sosial.

Terkait dengan perilaku kesehatan, maka perilaku kesehatan adalah suatu respon rasional atas penyebab penyakit yang dipersepsikan, sehingga dia mencari suatu cara untuk mendapatkan kesembuhan dari sakitnya. Selanjutnya, dalam menelaah tentang persepsi sakit ini, dibedakan antara rasa sakit (illness) dan penyakit (disease). Illness adalah penilaian seseorang terhadap penyakit sehubungan dengan pengalaman yang langsung dialaminya (Bashin, 2007). Hal ini merupakan fenomena subjektif yang ditandai dengan perasaan tidak enak (feeling unwell). Sedangkan disease adalah suatu bentuk reaksi biologis terhadap suatu organisme, benda asing atau luka. Jadi penyebab sakit adalah persepsi dari individu yang sakit dan persepsi ini terjadi sebagai hasil pembelajaran dari lingkungannya. Sehingga, menurut perilaku kesehatan individu bisa dibagi menjadi tiga.

1) Individu mempersepsikan sakitnya sebagai sebuah penyakit yang disebabkan oleh bakteri/virus.

2) Individu mempersepsikan sakitnya sebagai sebuah penyakit yang disebabkan karena hal-hal non medis

3) Individu mempersepsikan sakitnya sebagai sebuah penyakit yang disebabkan karena hal-hal medis dan non medis.

Oleh karena itu persepsi seseorang tentang disease akan menentukan perilaku illnessnya. Lebih lanjut tentang persepsi sakit, Notoatmojo (1993) menjabarkan tentang batasan kedua pengertian illness dan disease. Dalam kedua istilah tersebut nampak adanya perbedaan konsep sehat dan sakit yang kemudian akan menimbulkan permasalahan konsep sehat - sakit di dalam masyarakat. Secara objektif seseorang terkena penyakit, salah satu organ tubuhnya terganggu fungsinya namun dia tidak merasa sakit. Atau sebaliknya, seseorang merasa sakit, merasakan sesuatu (illness) dalam tubuhnya, tetapi dari pemeriksaan klinis tidak diperoleh bukti bahwa dia sakit.

Pada mulanya, sebagian besar (92\%) penderita penyakit kaki gajah kronis di Kabupaten Bandung mempersepsikan sakitnya sebagai akibat hal-hal non medis (santet, kutukan). Oleh karenanya 92\% penderita penyakit kaki gajah kronis di Kabupaten Bandung pernah mempercayakan pengobatannya kepada paranormal. Setelah mereka mendapat informasi tentang penyakit yang dideritanya melalui media televisi sebagian dari mereka memeriksakan diri ke pelayanan medis yang ada di puskesmas dan atau rumah sakit. Namun karena kurangnya informasi yang mereka terima, hanya $23 \%$ yang tetap mempercayakan pengobatan kepada tenaga medis, sisanya beralih kepada pengobatan tenaga kesehatan non dokter (akupunktur) dan pengobatan herbal. Karena mereka tidak merasakan perubahan kondisi kesehatan dari pengobatan yang diterimanya, sebagian berobat kepada paranormal di berbagai daerah. Satu orang penderita penyakit kaki gajah kronis di Kabupaten Bandung tetap berusaha mencari pengobatan bagi penyakitnya hingga melakukan operasi di rumah sakit negeri di Bandung. Namun setelah melakukan usaha pencarian pengobatan ke berbagai tempat tanpa menerima hasil yang bermakna, saat penelitian ini dilakukan, sebagian besar (92\%) sudah berhenti melakukan pencarian pengobatan. 
Perilaku kesehatan seperti halnya perilaku pada umumnya melibatkan banyak faktor. Menurut Lawrence Green (1980) kesehatan seseorang atau masyarakat dipengaruhi oleh dua hal pokok yaitu faktor perilaku dan di luar perilaku. Selanjutnya perilaku itu sendiri dipengaruhi oleh 3 faktor yaitu:

- Faktor pembawa ( predisposing factor ) didalamnya termasuk pengetahuan, sikap, kepercayaan, keyakinan, nilai nilai dan lain sebagainya.

- Faktor pendukung ( enabling factor ) yang terwujut dalam lingkungan fisik, sumber daya, tersedia atau tidak tersedianya fasilitas dan sarana kesehatan.

- Faktor pendorong ( reinforcing factor ) yang terwujut di dalam sikap dan perilaku petugas kesehatan maupun petugas lain, teman, tokoh yang semuanya bisa menjadi kelompok referensi dari perilaku masyarakat.

Berdasarkan faktor-faktor di atas dapat disimpulkan bahwa perilaku penderita penyakit kaki gajah tentang kesehatan ditentukan oleh pengetahuan, sikap, kepercayaan, tradisi dari orang yang bersangkutan. Disamping itu ketersediaan fasilitas kesehatan dan perilaku petugas kesehatan juga mendukung dan memperkuat terbentuknya perilaku.

Munculnya fenomena pencarian pengobatan kepada paranormal di kabupaten Bandung sebagai perilaku kesehatan masyarakat adalah suatu respon rasional masyarakat yang sedang berperanan sakit dalam rangka mencari kesembuhan akan penyakitnya. Beberapa sebab dan alasan pemilihan pengobatan di kabupaten Bandung ialah:

1) Budaya dan nilai sebagian besar masyarakat Kabupaten Bandung yang meyakini dan mempersepsikan penyebab sakit individu selain sebab medis dimungkinkan adanya sebab-sebab nonmedis seperti kutukan/guna-guna dari orang yang tidak suka kepada mereka.
2) Proses pengobatan yang terlalu lama dari pelayanan medis tanpa memberikan hasil karena hingga saat ini pembengkakan pada penyakit kaki gajah kronis belum ada obatnya. Hal ini menyebabkan si penderita bosan menerima peran sebagai pasien, dan ingin segera mengakhirinya, oleh karena itu dia berusaha mencari alternatif pengobatan lain yang mempercepat proses penyembuhannya ataupun hanya memperingan rasa sakitnya (illness).

3) Pelayanan medis yang kurang memperhatikan aspek psikologis pasien, dimana dalam pelayanan medis pasien tidak menemukan ketenangan dan keamanan psikologis, sehingga peluang ini diisi oleh para ahli non-medis.

4) Status sosial masyarakat Kabupaten Bandung yang mempersepsikan sakit bahwa pengobatan non medis lebih sedikit membutuhkan tenaga, biaya, dan waktu.

5) Status ekonomi sebagian besar masyarakat yang masih rendah, membuat mereka lebih menyukai pengobatan pada sakitnya ke tempat pengobatan yang tidak membutuhkan biaya tinggi seperti operasi di rumah sakit.

6) Tingkat pendidikan yang masih rendah serta kurangnya informasi kesehatan yang diterima menyebabkan sebagaian besar masyarakat kurang menyadari bahaya penyakit kaki gajah, cara penularan, cara pencegahan penyakit, dan pembatasan kecacatan. Masyarakat Kabupaten Bandung tidak mengetahui bahwa penyakit kaki gajah disebabkan oleh cacing yang berukuran sangat kecil dan ditularkan melalui cucukan nyamuk. Mereka mengira bahwa penyebab penyakit ini ialah guna-guna sehingga mencari pengobatan ke paranormal/non medis.

7) Persepsi tentang illness dan disease setiap individu yang berbeda-beda. Oleh sebab itu, perilaku kesehatan masing-masing individu pun akan mengalami perbedaan. Tidak ada satu perilaku kesehatan individu yang sama 
dalam mencari alternative penyembuhan, karena memang setiap individu memiliki karakteristik perilaku sendirisendiri.

Ada beberapa faktor sosial yang berpengaruh pada perilaku kesehatan antara lain

1. Konsep diri (H Ray Elling, 1980).

2. Pendapat kelompok (H Ray Elling, 1980).

3. Pengaruh identifikasi kelompok sosialnya terhadap perilaku kesehatan (Foster, 1973)

Pada konsep diri, kita ditentukan oleh tingkat kepuasan atau tidak kepuasan yang kita rasakan terhadap diri kita sendiri, terutama bagaimana kita ingin memperlihatkan diri kita kepada orang lain. Dengan demikian kita cenderung menentukan, apakah kita akan menerima keadaan diri kita seperti adanya atau berusaha untuk mengubahnya. Konsep diri adalah faktor yang penting dalam kesehatan,karena mempengaruhi perilaku masyarakat dan juga perilaku petugas kesehatan. Pemaknaan "pasrah" atau "tawakal" yang salah di mana kepasrahan terjadi tanpa diawali oleh usaha yang maksimal merupakan konsep diri yang keliru. Pemilihan tempat berobat yang salah menyebabkan penderita penyakit kaki gajah jenuh dengan pengobatan dan jatuh pada kondisi pasrah merasa bahwa semua sudah suratan sehingga tidak mau lagi mencari pengobatan bagi dirinya. Beberapa penderita merasa bahwa penyakit yang dideritanya sudah menjadi takdir untuk menghapuskan dosa-dosanya sehingga penderita penyakit kaki gajah berhenti mencari pengobatan. Pemaknaan pasrah ini kemudian menjadi rancu dengan kondisi putus asa.

Image seseorang individu sangat dipengaruhi oleh image kelompok. Di Kabupaten Bandung, beban psikologis penderita penyakit kaki gajah kronis diperparah dengan kurangnya rasa empati, pengetahuan, dan rasa persaudaraan dari masyarakat sekitar yang menjadikan penderita sebagai bahan pembicaraan bahkan malu bertetangga dengan penderita. Bahkan pada hasil wawancara kepada salah satu informan di Kabupaten Bandung, terdapat warga yang berniat mengumpulkan uang untuk diberikan kepada penderita supaya penderita pindah meninggalkan daerah tersebut. Hal ini tentu menambah beban psikologi penderita yang sudah berat sehingga penderita penyakit kaki gajah menutup diri di dalam rumah dan malu untuk mencari pengobatan.

Identifikasi kelompok kecilnya sangat penting untuk memberikan keamanan psikologis dan kepuasan dalam pekerjaan mereka. Sebanyak 7 (54\%) penderita penyakit kaki gajah mula-mula bekerja sebagai petani, kini tidak lagi bekerja karena sering dihina oleh teman-teman seprofesi petani. Sebanyak 2 orang yang membuka usaha $(15,4 \%)$ juga mengalami kendala sehingga terpaksa meminta keluarganya untuk mengelola usaha kecil yang didirikannya tersebut karena masyarakat sekitar tidak lagi memberikan keamanan psikologis ketika penderita tersebut menjalankan usahanya.

\section{SIMPULAN DAN SARAN}

Penyakit kaki gajah dapat menyebabkan kecacatan fisik, stigma sosial, serta penurunan kualitas hidup. Jika sudah terjadi pem-bengkakan anggota badan pada penderita penyakit kaki gajah kronis, belum ada pengobatan yang efektif dapat mengecilkan dan mengembalikan ke bentuk dan ukuran semula. Hal ini tentu berdampak kepada psikologi penderita. Hingga saat ini belum ada konsep pendekatan yang dilakukan untuk menangani permasalahan psikologis penderita penyakti kaki gajah. Penelitian ini bertujuan mengeksplorasi tinjauan psikologi kesehatan terhadap penderita penyakit kaki gajah kronis di Kabupaten Bandung.

Hasil dari penelitian ini menyimpulkan bahwa terdapat tiga dinamika psikologis yang dialami penderita penyakit kaki gajah kronis di Kabupaten Bandung yaitu: penolakan, cemas, dan depresi. Kon- 
disi psikis cemas merupakan kondisi terbanyak yaitu $85 \%$ dari subjek penelitian atau responden. Perilaku penderita terhadap penyakit kaki gajah di kabupaten bandung terhadap penyakit yang dideritanya yaitu sebagian besar yaitu 10 dari 13 orang responden menutupi penyakitnya, 8 dari 10 penderita yang menutup diri baru mengetahui penyakit yang dideritanya dari berita di televisi. Sikap tertutup ini didasari oleh rasa malu dan kekhawatiran akan dijauhi oleh orang lain karena takut tertular oleh mereka. Hal ini disebabkan karena minimnya pengetahuan penderita penyakit kaki gajah dan penduduk Kabupaten Bandung tentang cara penularan penyakit ini.

Pola perilaku pencarian pengobatan pada penderita penyakit kaki gajah kronis di Kabupaten Bandung terdiri atas: pernah mempercayakan pemeliharaan kesehatannya kepada paranormal (92\%), seorang ahli kesehatan profesional seperti dokter $(23 \%)$, ahli kesehatan non dokter seperti ahli akupunktur (15\%), dan pengobatan tradisional seperti jamu-jamu dan refleksi tradisional (54\%). Namun kini 92\% penderita telah berhenti melakukan pencarian pengobatan.

Perilaku penderita penyakit kaki gajah di Kabupaten Bandung terhadap kesehatan ditentukan oleh pengetahuan, sikap, kepercayaan, tradisi dari responden. Disamping itu ketersediaan fasilitas kesehatan dan periaku petugas kesehatan juga mendukung dan memperkuat terbentuknya perilaku. Sebagaimana yang telah diketahui bersama, menciptakan kembali kehidupan sosial pasien penderita penyakit kronis merupakan aspek yang penting. Bentuk sumber daya sosial yang dapat membantu individu yang menderita penyakit kronis misalnya dengan pemberi-an informasi, bantuan dan dukungan emosional. Partisipasi keluarga dan warga sekitar dalam proses rehabilitasi merupakan sesuatu yang sangat dianjurkan. Memberikan informasi pada anggota keluarga lain dan tetangga penderita yang akurat dan cukup mengenai keadaan individu yangs sakit (misalnya gangguan atau penyakit yang dialaminya, cara penularan, proses atau treatment yang akan dijalaninya bahka perubahan emosio-nal yang terlihat) merupakan sesuatu yang penting untuk dilaksanakan agar terhindar dari kebingungan dan kesalahpahaman dalam berkomunikasi antara individu yang sakit dengan pihak keluarga dan warga sekitar. Dalam banyak ayat dalam Alquran, Allah mengisyaratkan betapa pentingnya kita memelihara kebersihan hati dan jiwa itu. "Dan barang siapa yang beriman kepada Allah, niscaya Dia akan memberi petunjuk hatinya" (Q.S AlTagabun 64:11).

\section{DAFTAR PUSTAKA}

2011. Penderita Filariasis Harus

Dapat Stimulan Cacat Tetap. Harian Umum Pikiran Rakyat. Kamis, 29 December, 2011.

Agoes, R. 1982. Recent Outside Publications of Surveys and Research Works on Parasitology in Indonesia, A Literature Study Covering The 1970-1980 Period. Dalam: Sukandar,E., Masjur,JS, Agoes,R., Mukawi,T. Bunga Rampai Kedokteran. Ed ke-1. Bandung: Penerbit Alumni; 1982.

Bennuru,S, Nutman,TB. 2009. Lymphatic s in Human Lymphatic Filariasis: in Vitro Models of Parasite-Induced Lymphatic Remodeling. Lymphatic Research and Biology; 7(4):215-9.

Bhasin, V.2007. Medical Anthropology: A Review. Ethno-Med., 1(1): 1-20.

Bockarie,M.J., Taylor,MJ, and Gyapong,JO. 2009. Current practices in the management of lymphatic filariasis. Expert Review of Anti-infective Therapy;7(5):595605

Cohen,JE. and Small,C. 1998. Hypsographic Demography: The Distribution Of Human Population By Altitude. Proc. Natl. Acad. Sci. USA; 95:14009-14014. 
Cook. 1996. Manson's Tropical Diseases. $20^{\text {th }}$ Ed. London,W.B. Saunders Co.

Dinas Kesehatan Kabupaten Bandung. 2012. Data Penderita Filariasis Kabu-paten Bandung 2010-2011.

Ditjen PP dan PL Depkes, R.I. 2010. Program Eliminasi Filariasis di Indonesia. Workshop Sosialisasi Filariasis. Dinas Kesehatan Kabupaten Bandung.

Elling, RH. 1980. Cross-national study of health systems, concepts, methods, and data sources: a guide to information sources. London: Gale Research Co.

Fong MY, Asha T, Azdayanti M, et al. 2008. Inferring the phylogenetic position of Brugia pahangi using $18 \mathrm{~S}$ ribosomal RNA (18S rRNA) gene sequence. Trop Biomed ;25(1): 87-92.

Foster, G.M. 1973. Traditional Societies and Technological Change. London: Harper and Row.

Gani,A. 2010. Dampak Sosial dan Ekonomi Penyakit Kaki Gajah. Disampaikan pada Sosialisasi Filariasis Kabupaten Bandung. Soreang.

Helen F, McGarry, Leigh D, Plant and Taylor, MJ. 2005. Diethylcarbamazine Activity Against Brugia Malayi Microfilariae Is Dependent On Inducible Nitric-Oxide Synthase And The Cyclooxygenase Pathway. Filaria Journal, 4:4doi:10.1186/1475-2883-4-4.

Ilyas,I. 1990. Program Pemberantasan Filaria di Indonesia. Cermin Dunia Kedokteran; 64:3-6.

Machfoedz,I dan Suryani,E. 2008. Pendidikan Kesehatan dan Promosi Kesehatan. Yogyakarta: Fitramaya.

Kanjanopas, KK, Choochote,WW, Jitpakdi, AA, Suvannadabba,SS, Loymak, SS, Chungpivat, SS and Nithiuthai, SS. 2001. Brugia malayi in a naturally infected cat from Narathiwat Province, southern Thailand. Southeast Asian J Trop Med Public Health;32(3): 585-7.

Koentjaraningrat dan A.A Loedin. 1985. llmu-ilmu sosial dalam Pembangunan Kesehatan, Jakarta: PT Gramedia.

Kumari KA, Harichandrakumar KT, Das LK, Krishnamoorthy K. 2005. Physical And Psychosocial Burden Due To Lymphatic Filariasis As Perceived By Patients And Medical Experts. Trop Med Int Health. Jun;10(6):567-73.

Kurniawan,L. 1994. Filariasis - Aspek Klinis, Diagnosis, Pengobatan Dan Pemberantasannya. Cermin Dunia Kedokteran; 96:5-8.

Muzaham,Fauzi.1995. Sosiologi Kesehatan. Jakarta: Penerbit Universitas Indonesia.

Notoatmodjo, Soekidjo. 2010. Promosi kesehatan teori dan aplikasi. Jakarta; Rineka cipta.

Notoatmodjo, Soekidjo.2003. Pendidikan dan Perilaku Kesehatan. Jakarta: Rineka Cipta.

Oemijati, S. 1990. Masalah dalam Pemberantasan Filariasis di Indonesia. Cermin Dunia Kedokteran ;64:710.

Onggowaluyo, Ismid,IS, Sungkar,S. 1999. Dinamika Penularan Filariasis. Majalah Kedokteran Indonesia; 49(12): 518-22.

Palmieri JR, Masbar S, Purnomo, Marwoto HA, Tirtokusumo S, Darwis F.. 1985. The domestic cat as a host for Brugian filariasis in South Kalimantan (Borneo), Indonesia. $J$ Helminthol; 59(3): 277-81.

Rosenstock, IM. 1988. Enhancing patient compliance with health recommendations. Journal of Pediatric Health Care. Volume 2, Issue 2, March-April, Pages 67-72.

Sandosham, A.A. 1963. Review of Research in Parasitology in Malaya. Singapore Med J; 4(1):4251.[diunduh 21 Agustus 2011. 
Sasa, Manabu. 1979. A review on classification and geographic distribution on brugian filariasis. Joint WPRO/SEARO Working Group on Brugian Filariasis. [abstrak]. [diunduh 26 Juni 2010]; Tersedia dari World Health Organization:

http://whqlibdoc.who.int/wpro/1993/WG FIL 79.3.pdf

Sudomo,M. 1990. Aspek Epidemiologi Filariasis yang Berhubungan dengan Pemberantasannya. Cermin Dunia Kedokteran; 64:11-14.
Suma TK, Shenoy RK, Kumaraswami V. 2003. A Qualitative Study Of The Perceptions, Practices And SocioPsychological Suffering Related To Chronic Brugian Filariasis In Kerala, Southern India. Ann Trop Med Parasitol. Dec;97(8):839-45.

Taylor, EV. 2008. Transformative learning theory. New Directions for Adult and Continuing Education; Volume 2008, Issue 119, pages 515.

WHO. 2003. Control, Prevention, and Eradication. Community homebased prevention of disability due to lymphatic filariasis. Programme to Eliminate Lymphatic Filariasis. 